\title{
Antimicrobial potential of anaconda body fat oil (Eunectes murinus), in Santarém city, Pará state, Brazil
}

\author{
Potencial antimicrobiano do óleo da gordura corporal de \\ Sucuriju (Eunectes murinus), em Santarém, Pará, Brasil
}

\author{
Lidiane Nascimento Araúijo* (D), Christian Hermes Ribeiro Batista² (D), Osvaldo Gato Nunes Neto ${ }^{3}$ (i) \\ Hipócrates de Menezes Chalkidis ${ }^{4,5}$ (1D) \& Welligton Conceição da Silva ${ }^{6}$ (1) \\ 'Veterinarian, Pós-graduação em Sociedade, Ambiente e Qualidade de Vida (PPGSAQ), Universidade Federal do Oeste do Pará \\ (UFOPA), Santarém, PA, Brasil. \\ ${ }^{2}$ Veterinarian, autonomous, Santarém, PA, Brasil. \\ 3Veterinarian, MSc., Programa de Pós-graduação Doutorado em Sociedade, Natureza e Desenvolvimento (PPG-SND), UFOPA \\ Santarém, PA, Brasil. \\ ${ }^{4}$ Biologist, Centro Universitário da Amazônia, Santarém, Pará, Brasil. \\ 5Veterinarian, Programa de Pós-graduação em Saúde e. Produção Animal na Amazônia. (PPGSPAA), Universidade Federal Rural \\ da Amazônia (UFRA), Belém, PA, Brasil
}

\begin{abstract}
The use of natural substances from animals and plants has always been the subject of research, because it is made in a rustic way and through popular knowledge, built by everyday experiences and without scientific approval. The oil from the body fat of the snake - or better known as lard of anaconda, extracted from the anaconda snake (Eunectes murinus) is a product widely used in traditional communities and is marketed in markets for therapeutic purposes in several diseases. Because of the low cost and popular beliefs, many people use zootherapeutic means to treat themselves. Hence the importance of therapeutic proof of these products. Thus, the aim of this study was to verify whether the lard of anaconda made in the traditional way has antimicrobial potential in certain strains of pathogenic bacteria and fungi. For that, the evaluation of the lard's antimicrobial potential was carried out using the disk diffusion method, adapted from the manual M7-A6 standardized by the Clinical and Laboratory Standards Institute, against the strains of Staphylococcus aureus, Escherichia coli, Candida albicans and C. krusei. The observed results showed that there was no presence of bacterial or yeast growth inhibition halos, indicating that the anaconda lard oil did not inhibit the growth of fungi and bacteria in any of the strains used. Therefore, the present study allows us to conclude that the anaconda lard oil (E. murinus), did not present any inhibitory antimicrobial potential, against the tested bacterial and fungal strains.
\end{abstract}

Keywords: traditional knowledge, zootherapy, snake, bacteria.

\section{Resumo}

O uso de substâncias naturais provenientes de animais e plantas sempre foi alvo de pesquisas, por ser feito de forma rustica e através de saberes populares, construídos por experiências no cotidiano e sem aprovação científica. Oóleo dagordura corporal da serpente-ou mais conhecida como banha de sucuriju, extraída da serpente sucuri (Eunectes murinus) é um produto muito utilizado em comunidades tradicionais eé comercializada em mercados com finalidade terapêutica em diversas moléstias. Por conta do baixo custo e de crenças populares, muitas pessoas utilizam de meios zooterápicos para se tratar por si mesmo. Daíaimportância da comprovação terapêutica desses produtos. Assim, o objetivo nesteestudo foi verificar se abanha de sucuriju confeccionada de modo tradicional possui potencial antimicrobiano, em determinadas cepas de bactérias efungos patogênicos. Paraisso a avaliação do potencial antimicrobiano da banha, foi realizada através do método de difusão em disco, adaptado do manual M7-A6 padronizado pelo "Clinicaland Laboratory Standards Institute", frente às cepas de Staphylococcus aureus, Escherichia coli, Candida albicans e C. krusei. Os resultados observados demonstraram que não houve a presença de halos de inibição de crescimento bacteriano ou leveduriformes, indicando que o óleo da banha de sucuriju não inibiu o crescimento de fungos e bactérias em nenhuma das cepas utilizadas. Portanto, o presente estudo permite concluir que o óleo da banha de sucuriju (E. murinus), não apresentou nenhum potencial antimicrobiano inibitório, frente às cepas bacterianas e fúngicas testadas.

Palavras-chave: conhecimento tradicional, zooterapia, serpente, bactérias.
How to cite: Araújo, L. N., Batista, C. H. R., Nunes Neto, O. G., Chalkidis, H. M., \& Silva, W. C. (2020) Antimicrobial Potential of anaconda body fat oil (Eunectes murinus), in Santarém city, Pará state, Brazil. Brazilian Journal of Veterinary Medicine, 42, e112920. https:/doi.org/10.29374/2527-2179. bjvm112920

Financial support: None.

Conflict of interests: No conflict of interests declared concerning the publication of this article.

Received: June 07,2020

Accepted: September 15, 2020

The study was carried out at Laboratório de Pesquisas Zoológicas - LPZ, Centro Universitário da Amazônia - UNAMA, Santarém, PR, Brasil.

\section{*Correspondence}

Lidiane Nascimento Araújo

Universidade Federal do Oeste do Pará -

UFOPA

Avenida Mendonça furtado, NO 2.946, Bairro: Fátima,

CEP 68040-470

E-mail: lidiane.niltonlins@gmail.com 


\section{Introduction}

Fungi and bacteria are agents that promote health problems in both humans and animals. Bacteria have been living in the terrestrial environment for approximately 3.5 billion years, surviving temperature fluctuations, lack of nutrients, ultraviolet radiation and other external factors. These agents have a high adaptive and transmutation capacity that is linked to their genomic structure, which gives them the exchange of genes between bacteria (EmyInumaru et al., 2019). Thus, bacteria began to promote infectious processes that were only discovered in the $19^{\text {th }}$ century when research related to these pathogens began (Sousa et al., 2019).

Therefore, different substances and drugs were produced, such as antimicrobials that are natural substances (antibiotics) or synthetic (chemotherapy) that act on microorganisms leading to inhibition of their growth or causing their destruction (Sáez-Llorens et al., 2000). Due to the great increase in the resistance of pathogenic microorganisms to multiple drugs, due to the indiscriminate use of antimicrobials, there is a concern for the search for new therapeutic alternatives (Novais et al., 2003, Antunes et al., 2006; Oliveira et al., 2006, 2007).

Natural products are an extremely viable alternative, since they have always been important for the discovery of new drugs, being suppliers of active ingredients and because they are also a more economical alternative in disease control for developing countries, where most drugs are imported (Xu \& Lee 2001). In Brazil, several species of animals have been used for medicinal purposes since colonization, representing a therapeutic alternative widely disseminated throughout the country (Alves \& Rosa 2006, 2007).

In view of the varied uses of animals, the use specifically for medicinal purposes is known as Zootherapy (Marques 1994; Alves \& Rosa 2005).This may be understood as the use of medicines made from animal body parts, products of their metabolism (such as body secretions and excrement) or materials built by them, such as nests and cocoons (Costa-Neto \& Alves 2010).

Among reptiles, the anaconda snake (E. murinus), is an example of an animal species widely used by the riverside population to combat some types of diseases. This animal's fat is used as antibiotics for inflammation and respiratory processes, as well as in the treatment of bone and muscle diseases (Silva, 2008).

The knowledge of the antimicrobial potential of natural products is necessary for a better understanding of their properties, proof of their effectiveness and the development of more complex drugs, which are difficult to adapt (Daferera et al., 2003). Thus, the aim of this study was to verify whether the lard of anaconda made in the traditional way has antimicrobial potential in certain strains of pathogenic bacteria and fungi.

\section{Materials and method}

\section{Specimen}

The specimen used in this research came from the region of Lago Grande do Curuai, which has communities spread over the floodplain and terra firme area, located in Santarém city, Pará state, under authorization SISBIO 14018-11. The preparation of the product was handmade: the fat located in the peritoneum region was removed and placed in a container to be prepared through cooking and the supernatant stored in small plastic containers. In the laboratory, the oil was placed in a bain-marie at 430 for 10 minutes to obtain its liquefaction, conditioned and kept in eppendorf tubes for further analysis. For the preparation of the solution, $100 \mathrm{mg}$ of the sample was solubilized in 900 ml of Dimethyl Sulfoxide (DMSO - Merck, Darmstadt, Germany), to obtain an initial concentration of $100 \mathrm{mg} / \mathrm{ml}$.

\section{Disk diffusion method}

The evaluation of the antimicrobial potential of the anaconda lard was carried out through a qualitative biological assay, in triplicate, using as positive controls the antibiotic chloramphenicol (10 $\mu \mathrm{g}$ ) for Staphylococcus aureus and Escherichia coli; nystatin (250 $\mu \mathrm{g}$ ) for Candida albicans and C. krusei. The test was performed using the disk diffusion method, adapted from the manual M7-A6 standardized by the Clinical and Laboratory Standards Institute (2003). 
In Petri dishes containing $10 \mathrm{ml}$ of Müller-Hinton agar $(\mathrm{MH})$, the following microbial strains were inoculated with a swab on the surface of the growth medium: S. aureus (ATCC 25923), E. coli (ATCC 29922), C. albicans (ACLI) and C. krusei (ACLI).The inoculants have a concentration of $108 \mathrm{CFU} / \mathrm{ml}$, originating from a previous culture in MH and SDA medium (Sabouraud Dextrose Agar) for 24 hours. The inoculum concentration was adjusted using a 0.5 MacFarland scale. Subsequently, on Whatman paper discs no. 4 (diameter $5 \mathrm{~mm}$ ) sterilized, $10 \mu \mathrm{l}$ of solutions at $100 \mathrm{mg} / \mathrm{ml}$ of lard were applied. Then, each plate received five paper disks, one being the positive control receiving the antibiotic or antifungal, a negative control containing DMSO and the assay triplicate. After the distribution of these discs, the plates were incubated at $37{ }^{\circ} \mathrm{C}$ for 24 and $48 \mathrm{~h}$, respectively, for bacteria and yeast. After incubation, the reading of the bacterial or yeast growth inhibition halos was performed.

\section{Results and discussion}

There was no presence of bacterial or yeast growth inhibition halos, indicating that the anaconda body fat oil did not inhibit the growth of fungi and bacteria in any of the strains used (Figure 1A, B, C and D), revealing that this isolated product has no efficacy in the control of microorganisms, and its use by traditional medicine on diseases caused by infectious agents, has no pharmacological basis.
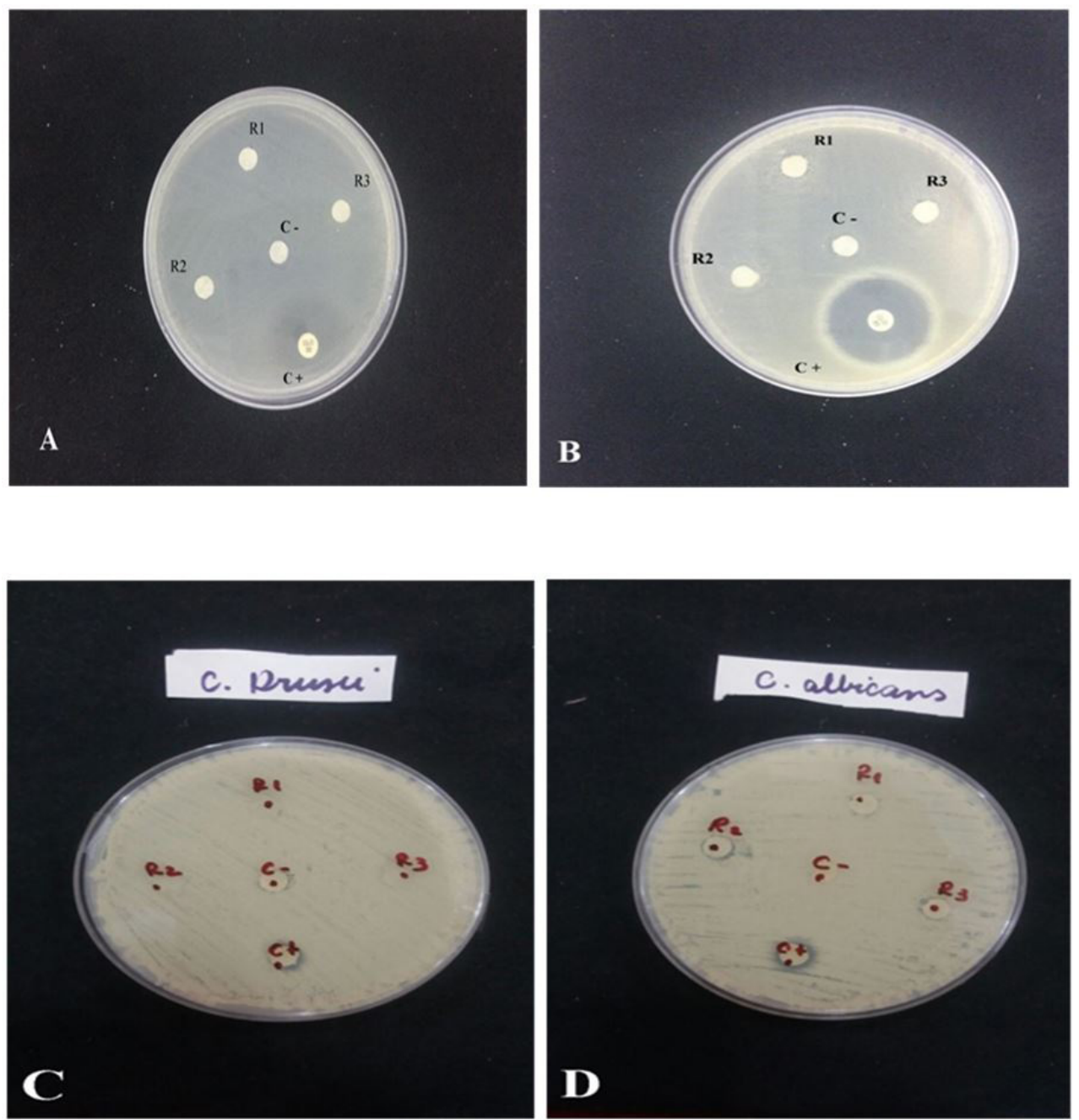

Figure 1. Photographic records of the antimicrobial assay of the anaconda body fat oil (Eunectes murinus) against Staphylococcus aureus isolates (A), Escherichia coli (B). R1, R2, R3 (triplicate): Anaconda lard + DMSO; C - (negative control): DMSO; C + (positive control): chloramphenicol. Candida krusei (C), Candida albicans (D). R1, R2, R3 (triplicate): Anacondalard + DMSO; C - (negative control): DMSO; C + (positive control): nystatin. 
In this study, the ineffectiveness in microbial control using anaconda body fat oil was observed, corroborating the study by Ferreira et al. (2009) who performed a work using the fixed oil extracted from the body fat of representatives of herpetological fauna, such as that of Tupinambis merianae, where the results showed that the oil tested in isolation did not present antibacterial activity, with clinical relevance, against the strains standard and multidrug-resistant E. coli and S. aureus, similar results were observed by Sales (2012) with Rhinella jimi, where he demonstrated that the oil administration alone did not present clinically relevant antimicrobial activity. Similar results were observed in the study by Cabral (2012) with Leptodactylus macrosternum and L. vastus, where the oils tested alone did not show significant inhibitory action on bacterial and fungal growth against most of the tested strains, except for the Pseudomonas aeruginosa ATCC strains 15442 and C. krusei ATCC 6258, respectively. Furthermore, Oliveira (2013) using Spilotes pullatus, found that the oil did not inhibit the growth of fungi and bacteria used.

In contrast, presenting different results from this study, other studies have demonstrated the antimicrobial action of natural products from reptiles. Falodun et al. (2008) and Ferreira et al. (2011) showed that the fat of the Boa constrictor snake has antibacterial and antibiotic modulating activity, respectively. Dias (2013) indicated that the fixed oil of the chelonian Phrynops geoffroanus when analyzed separately against the strains of fungi and bacteria tested, showed antifungal activity from the clinical point of view for C. krusei ATCC 6258.

Ciscotto et al. (2009) describe the bactericidal and antiparasitic activity of L-amino-acid oxidase from the venom of the snake Bothrops jararaca, corroborating with Morais et al. (2009) who report the anticoagulant activity of the B. jararaca venom's antithrombin, similar results were observed by Liu et al. (2008) who demonstrated an anti-tumor activity of extracts from the lizard Gekko japonicus widely used in traditional Chinese medicine. The researches, previously mentioned, disagree with the present study, which did not identify the antimicrobial potential of anaconda body fat oil (E. murinus ) on the strains of bacteria and fungi evaluated.

Dias \& Monteiro (2010) describe that due to a worrying reality with the control of bacteria and fungi, which is the resistance developed to existing drugs, with loss of their effectiveness. For Duarte (2006) the development of new drugs, as well as the bioprospecting for new antimicrobial substances from natural sources has been increasing the interest of pharmaceutical companies.

\section{Conclusion}

The body fat oil of anaconda (E. murinus), did not present any inhibitory antimicrobial potential in relation to the tested bacterial and fungal strains.

\section{References}

Alves, R. R., \& Rosa, I. L. (2005). Why study the use of animal products in traditional medicines? Journal of Ethnobiology and Ethnomedicine, 30(1), 5. http://dx.doi.org/10.1186/1746-4269-1-1. PMid:16270931.

Alves, R. R., \& Rosa, I. L. (2006). From cnidarians to mammals: the use of animals as remedies in fishing communities in NE Brazil. Journal of Ethnopharmacology, 107(2), 259-276. PMID: 16621379.

Alves, R. R., \& Rosa, I. M. (2007). Biodiversity, traditional medicine and public health: where do they meet? Journal of Ethnobiology and Ethnomedicine, 3(14), 1-9. http://dx.doi.org/10.1186/1746-4269-3-14. PMid:17376227.

Antunes, R. M. P., Lima, E. O., Pereira, M. S. V., Camara, C. A., Arruda, T. A., Catão, R. M. R., Barbosa, T. P., Nunes, X. P., Dias, C. S., \& Silva, T. M. S. (2006). Atividade antimicrobiana "in vitro" e determinação da concentração inibitória mínima (CIM) de fito constituintes e produtos sintéticos sobre bactérias e fungos leveduriformes. Revista Brasileira de Farmacognosia, 16(4), 517-524. http://dx.doi.org/10.1590/S0102-695X2006000400014.

Cabral, M. E. S. (2012). Identificação química, análise microbiológica e farmacológica das gorduras corporais de Leptodactylus macrosternum (Miranda-Ribeiro, 1926) e Leptodactylus vastus (Adolf Lutz, 1930) da Região do Cariri (Dissertação de mestrado). Universidade Regional do Cariri, Crati.

Ciscotto, P., Machado de Avila, R. A., Coelho, E. A., Oliveira, J., Diniz, C. G., Farías, L. M., de Carvalho, M. A., Maria, W. S., Sanchez, E. F., Borges, A., \& Chávez-Olórtegui, C. (2009). Antigenic, microbicidal and antiparasitic properties of an l-amino acid oxidase isolated from Bothrops jararaca snake venom. Toxicon: official journal of the International Society on Toxinology, 53(3), 330-341. http://dx.doi.org/10.1016/j.toxicon.2008.12.004. PMid:19101583.

Clinical and Laboratory Standards Institute - CLSI. (2003). Performance standards for antimicrobial disk susceptibility tests (8th ed.). Wayne: Clinical and Laboratory Standards Institute. Approved Standard M2-A8.

Costa-Neto, E. M., \& Alves, R. R. N. Estado da arte da zooterapia popular no Brasil. In E. M. Costa-Neto \& R. R. N. Alves (Eds.), Zooterapia: os animais na medicina popular brasileira (pp. 15-54). Recife: NUPPEA, 2010. 
Daferera, D. J., Ziogas, B. N., \& Polissiou, M. G. (2003). The effectiveness of plant essential oils on the growth of Botrytis cinerea, Fusarium sp. and Clavibacter michiganensis sub sp. michiganensis. Crop Protection(Guildford, Surrey), 22(1), 39-44. http://dx.doi.org/10.1016/S0261-2194(02)00095-9.

Dias, D. Q. (2013). Estudo zooterápico do óleo fixo de Phrynops geoffroanus (Schweigger, 1812) (Testudines: Chelidae) do Nordeste do Brasil, com análise química e farmacológica (in vitro e in vivo) (Dissertação de mestrado). Universidade Regional do Cariri, Crato.

Dias, M., \& Monteiro M. S. (2010). Antibióticos e resistência bacteriana, velhas questões, novos desafios. Cadernos Otorrinolaringologia: Clínica, Investigação e Inovação. 1-12.

Duarte, M. C. T. (2006). Atividade antimicrobiana de plantas medicinais e aromáticas utilizadas no Brasil. MultiCiência, 7,1-16.

EmyInumaru, F., Silva, A. S., Soares, A. S., \& Schuelter-Trevisol, F. (2019). Perfil e uso adequado de antibióticos em crianças de um hospital geral do sul do Brasil. Revista Paulista de Pediatria: Orgao Oficial da Sociedade de Pediatria de Sao Paulo, 37(1), 27-33. http://dx.doi.org/10.1590/1984-0462/:2019;37;1;00011.

Falodun, A., Owolabi, O. J., \& Osahon, O. (2008). Physicochemical, antimicrobial and anti-inflammatory evaluation of fixed oil from Boa constrictor. Acta Poloniae Pharmaceutica, 65(4), 477-480. PMid:19051590.

Ferreira, F. S., Brito, S. V., Costa, J. G. M., Alves, R. R. N., Coutinho, H. D. M., \& Almeida, W. O. (2009). Is the body fat of the lizard Tupinambis merianae effective against bacterial infections? Journal of Ethnopharmacology, 126(2), 233-237. http://dx.doi.org/10.1016/j.jep.2009.08.038. PMid:19723574.

Ferreira, F. S., Silva, N. L. G., Matias, E. F. F., Brito, S. V., Oliveira, F. G., Costa, J. G. M., Coutinho, H. D. M., Almeida, W. O., \& Alves, R. R. N. (2011). Potentiation of amonoglycoside antibiotic activity using the body fat from the snake Boa constrictor. Revista Brasileira de Farmacognosia, 21(3), 503-509. http://dx.doi.org/10.1590/ S0102-695X2011005000088.

Liu, F., Wang, J. G., Wang, S. Y., Li, Y., Wu, Y. P., \& Xi, S. M. (2008). Antitumor effect and mechanism of Gecko on human esophageal carcinoma cell lines in vitro and xenografted sarcoma 180 in Kunming mice. World Journal of Gastroenterology, 14(25), 3990-3996. http://dx.doi.org/10.3748/wjg.14.3990. PMid:18609682.

Marques, J. G. W. (1994). A fauna medicinal dos índios Kuna de San Blas (Panamá) e a hipótese da universalidade zooterápica. In Anais da 46a Reunião Anual da SBPC. Vitória: Universidade Federal do Espírito Santo.

Morais, K. B., Vieira, C. O., Hirata, I. Y., \& Tanaka-Azevedo, A. M. (2009). Bothropsjararaca antitrombina: isolamento, caracterização e comparação com outros antitrombinos animais. Bioquímica Comparada e Fisiologia - Parte B: Bioquímica e Biologia Molecular, 152, 171-176.

Novais, T. S., Costa, J. F. O., David, J. P. L., David, J. M., Queiroz, L. P., França, F., Giulietti, A. M., Soares, M. B. P., \& Santos, R. R. (2003). Atividade antibacteriana em alguns extratos de vegetais do semiárido brasileiro. Revista Brasileira de Farmacognosia, 13(2), 5-8. http://dx.doi.org/10.1590/S0102-695X2003000400003.

Oliveira, F. P., Lima, E. O., Siqueira-Júnior, J. P., Souza, E. L., Santos, B. H. C., \& Barreto, H. M. (2006). Effectiveness of Lippia sidoides Cham. (Verbenaceae) essential oil in inhibiting the growth of Staphylococcus aureus strains isolated from clinical material. Revista Brasileira de Farmacognosia, 16(4), 510-516. http://dx.doi.org/10.1590/ S0102-695X2006000400013.

Oliveira, O. P. (2013). Avaliação da composição química e atividade antimicrobiana e anti-inflamatória do óleo extraído da gordura corporal de Spilotes pullatus (Linnaeus, 1758) (Colubridae: Ophidia) da Chapada do Araripe no Nordeste brasileiro (Dissertação de mestrado). Universidade Regional do Cariri, Crato.

Oliveira, R. A. G., Lima, E. O., Souza, E. L., Vieira, W. L., Freire, K. R. L., Trajano, V. N., Lima, I. O., \& Silva-Filho, R. N. (2007). Interference of Plectranthus amboinicus (Lour.) Spreng essential oil on the anti-Candida activity of some clinically used antifungals. Revista Brasileira de Farmacognosia, 17(2), 186-190. http://dx.doi.org/10.1590/ $\underline{\mathrm{s} 0102-695 \times 2007000200009}$.

Sáez-Llorens, X., Castrejón de Wong, M. M., Castaño, E., De Suman, O., De Morös, D., \& De Atencio, I. (2000). Impact of an antibiotic restriction policy on hospital expenditures and bacterial susceptibilities: a lesson from a pediatric institution in a developing country. The Pediatric Infectious Disease Journal, 19(3), 200-206. http://dx.doi.org/10.1097/00006454-200003000-00005. PMid:10749459.

Sales, D. L. (2012). Identificação química e avaliação das atividades antimicrobiana e antiinflamatória do óleo fixo extraído da gordura de Rhinellajimi (Stevaux, 2002) (Anura: Bufonidae) (Dissertação de mestrado). Universidade Regional do Cariri, Crato.

Silva, A. L. (2008). Animais medicinais: conhecimento e uso entre as populações ribeirinhas do rio Negro, Amazonas, Brasil. Boletim do Museu Paraense Emílio Goeldi, 3(3), 343-357. http://dx.doi.org/10.1590/ S1981-81222008000300005.

Sousa, C. T., Frade, V. P., Vieira, L., Souza Sales, T. L., Alves Gomes, G. K., \& Sanches, C. (2019). Alterações farmacocinéticas de antimicrobianos em situações especiais: uma revisão narrativa. Revista Ciencia Médica, 27(3), 135-155. http://dx.doi.org/10.24220/2318-0897v27n3a4014.

Xu, H. X., \& Lee, S. F. (2001). Activity of plant flavonoids against antibiotic-resistant bacteria. Phytotherapy Research, 15(1), 39-43. http://dx.doi.org/10.1002/1099-1573(200102)15:1<39::AID-PTR684>3.0.CO;2-R. PMid:11180521. 